\title{
MATURITY ASSESSMENT OF MAINTENANCE PROCESSES AT ATC-SERVICE PROVIDERS
}

\author{
Jörg Kundler \\ Head of IT-Services \& Infrastructure DFS, Deutsche Flugsicherung GmbH, \\ Am DFS-Campus 7, D-63225 Langen \\ Ph.+496103707 2530.Fax+4961037074596.E-mail: Joerg.Kundler@dfs.de
}

\begin{abstract}
The focus of the research is the analysis and assessment of Air Traffic Control (ATC) maintenance and technical service processes. Deriving from the general ATC process model, which is the part of the Air Transport System, the related ATC Services including a Key Performance Indicator System were developed. A theoretical analysis was performed to develop a special correlation matrix between the Air Transport System to ATC service and ATC technical services, which reflect the top-down approach of process modelling proceeding. A particular research of different international ATC service organization, selected by defined parameter was performed for analysis. The analysis was implemented with different scientific research methods. Basing on this international research, a detailed SWOT analysis and conclusions of each ATC organization itself and additionally a parameteroriented comparison between the different organizations and their specifics were performed. The results of this research were described in a SWOT analysis, rating assessment of utilization of the theoretical methods and qualified evaluation of implemented KPI System. For final maintenance process evaluation an ATC-Maintenance Process Maturity method based on ISO /IEC Standard 15504 was developed. The results and developments of the research will be the essential prerequisite for the further research of dissertation and development of a harmonized ATC Meta Frame Maintenance Process Model as a part of the Air Transport System on macro model level and deriving to the ATC specific Maintenance Service Model on micro level for the specific ATC organization basing on service and business modelling methods.
\end{abstract}

Keywords: ATC Maintenance Process Model, International Research, Process Maturity Assessment, Key Performance Indicator

The presented material reflects the results of investigations executed in frames of $\mathrm{PhD}$ study under the supervision of Dr.habil.sc.ing., Professor Igor Kabashkin.

\section{Problem Description and Derivation of the Research Objects}

This research is a part of doctoral thesis and is focused on researching the mentioned ATC maintenance technical service and process model in detail. The objects of the research are all the related processes to support the technical maintenance of ATS operational Systems, which support the ATC controllers. The actual research describes the technical maintenance and service processes for ATC organizations. The focus is on performing the analysis on a scientific level at different ATM organizations and their Maintenance Process Model. The goal is to use this analysis and conclusions to develop a harmonized ATM process model including a common metric system for measurement of the process and support quality. To perform this task a special method of multi-step analysis approach based on ISO/ IEC standard and assessment process was developed. In case of the European harmonization and actual realized FABEC program for the ATC technical maintenance the following areas of improvement and optimisation were detected:

- Missing service characteristics;

- No common definition and understanding of service oriented terms and support level;

- No definition of end-to-end services for ATC operational and technical services;

- No existing of ATC service modelling or common ATC service catalogue;

- Missing of service oriented architecture (SOA) of ATC systems;

- $\quad$ Missing of ATC common integrated service approach and methods.

The mentioned problem areas are significant because the European harmonization and implementation of FABs have a direct implication in the operational concepts of each national ATC service provider, in their methods and proceedings of operation, maintenance and technical support processes. The adaptation to the ATC maintenance process modelling is not reflected adequately and requires a complete harmonized ATC Service and maintenance process harmonization. The actual article discusses the developed method of ATM Maintenance Process and Service Evaluation, the developed evaluation criteria and assessment approach.

On Figure 1 goal and major steps of developed research approach are described. 


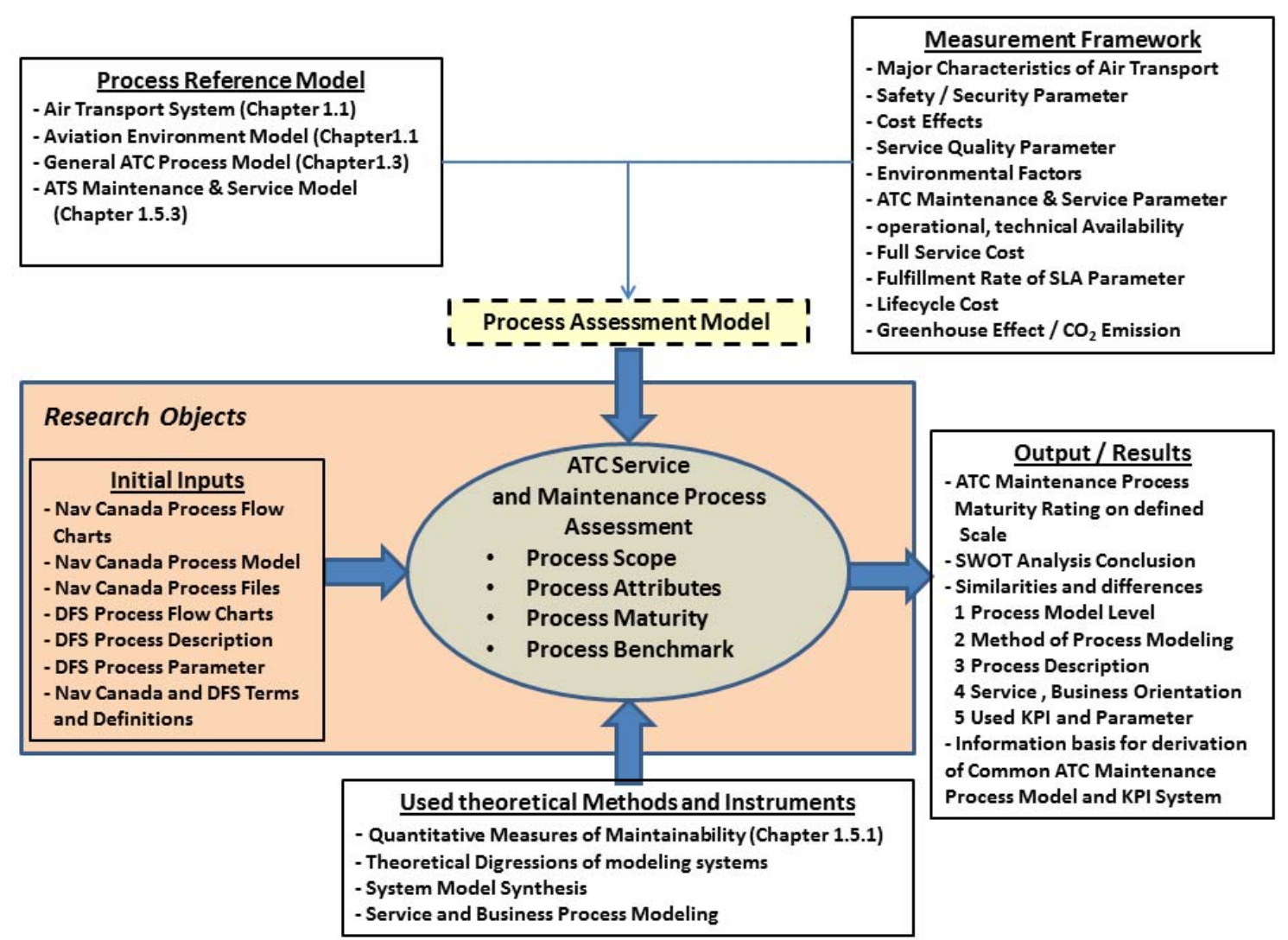

Figure 1. Approach of ATC Maintenance Process Research

\section{Theoretical Methods and Conditions for Analysis at ATC Maintenance Process}

The ATC providers have been selected based on developed criteria catalogue, which is described on Figure 2. It is important to select a mix of different ATC providers by organization form, company size, innovation and in relation to ATC harmonization programs due to the goal to get a common information feedback on international level. The selection is performed on the following process steps:

- Selection of ATC service organisation and qualified contact;

- Development and analysing of questionnaires;

- Perform different telephone interviews;

- Hold personal visits and interview.

The method of questionnaire is simple and with low effort. The information can be structured based on given question structure:

1. Introduction;

2. Methodology of Survey;

3. Research Objects;

4. Analysis of

4.1.1. Maintenance Process;

4.1.2. Standardization Level;

4.1.3. Process and Service Modelling;

5. Organisational Purposes;

6. Individual Feedback.

The handling via e-mail is easy and low cost related. Based on given open questions the answerer is able to give more "free" answers and have space to give an open feedback and experience. But the use of questionnaire has also disadvantages, like risk of misunderstanding of questions and non-response or partly- response answer. So it is of great importance to have network-people, who are able to open the access to the specialists. To reduce the mentioned disadvantages it was decided to perform in addition different telephone interviews and personal visits. Based on interviews it is possible to get more directly 
answers, more "non-verbal" information and personal experiences in form of personal discussion. For analysis a specific criteria catalogue and evaluation structure was developed. It was used for evaluation of questionnaire and interview information, reviewed documentation of ATC Providers.

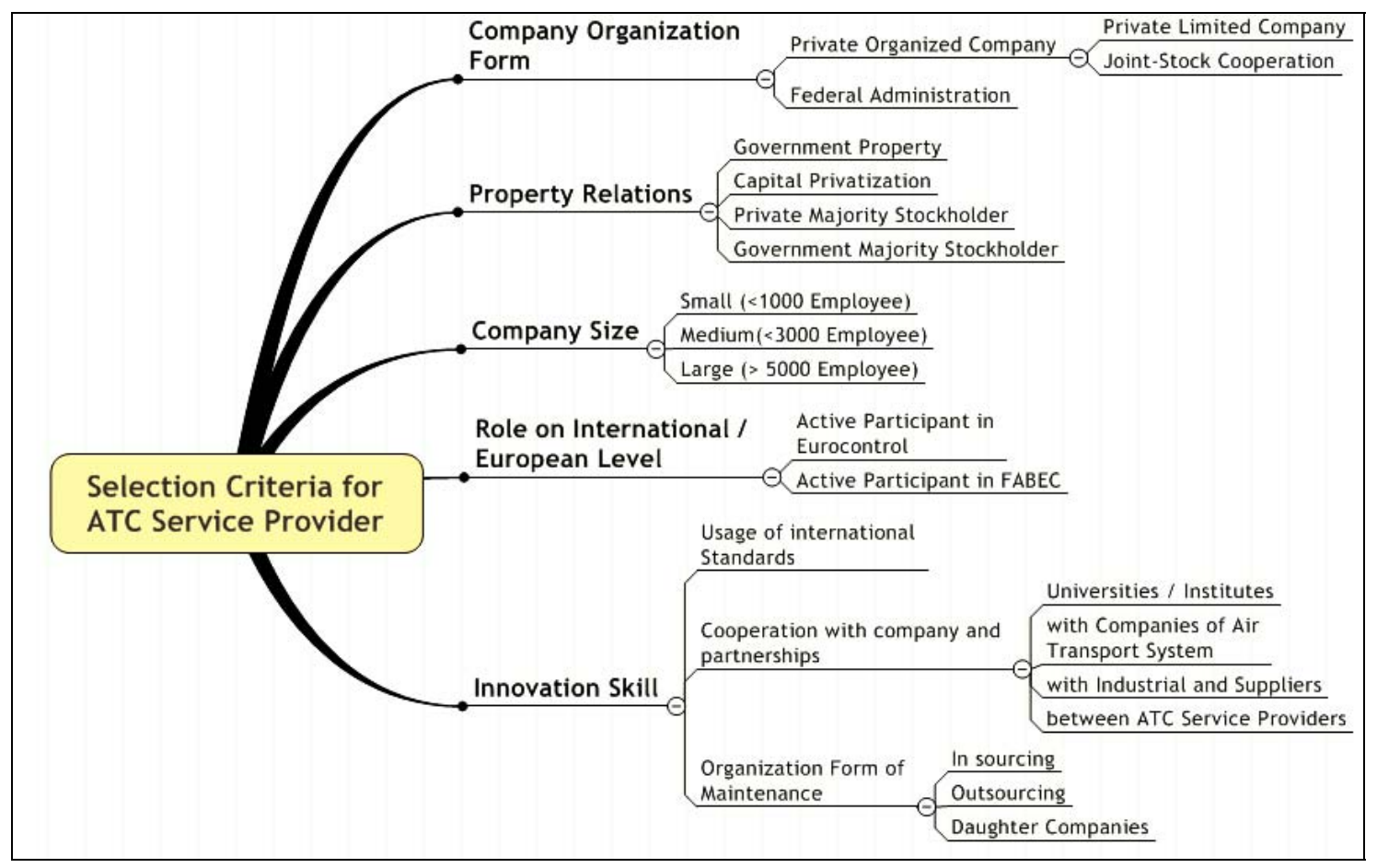

Figure 2. Set of Selection Criteria's for ATC Service providers

The evaluation based on the following methods:

$\rightarrow$ On descriptive methods, where analysis and evaluation in verbal structured form is done;

$\downarrow$ On binary evaluation methods, which in general give the information about existing or not existing of required criteria (Yes or No) and the related derivation;

$\rightarrow$ Maturity Level Analysis and Measurement (MLAM), this method is used to analysis and evaluation of different reached level of processes, standardization. The MLAM will be a major method.

Table 1. Overview of ATC Service Provider Analysis

\begin{tabular}{|l|l|l|l|l|l|l|l|}
\hline Criteria & $\begin{array}{l}\text { LGS } \\
\text { Latvia }\end{array}$ & $\begin{array}{l}\text { FAA } \\
\text { USA }\end{array}$ & Nav Canada & $\begin{array}{l}\text { NATS } \\
\text { UK }\end{array}$ & $\begin{array}{l}\text { LVF } \\
\text { Sweden }\end{array}$ & $\begin{array}{l}\text { DFS } \\
\text { Germany }\end{array}$ & $\begin{array}{l}\text { TTC } \\
\text { Germany }\end{array}$ \\
\hline $\begin{array}{l}\text { Delivery } \\
\text { of Information }\end{array}$ & $\begin{array}{l}\text { Questionnaire } \\
\text { Interview }\end{array}$ & $\begin{array}{l}\text { Questionnaire } \\
\text { Documentation }\end{array}$ & $\begin{array}{l}\text { Documentation } \\
\text { Interview } \\
\text { Documentation } \\
\text { Interview }\end{array}$ & $\begin{array}{l}\text { Questionnaire } \\
\text { Documentation } \\
\text { Interview }\end{array}$ \\
\hline Legal Status & Private & Public & Private & Private & Public & Private \\
\hline $\begin{array}{l}\text { Property } \\
\text { Relation }\end{array}$ & State Owner & $\begin{array}{l}\text { Gov } \\
\text { Administration }\end{array}$ & State Owner & $\begin{array}{l}\text { Private-State } \\
\text { Owner }\end{array}$ & State Owner & State Owner \\
\hline Company Size & Small & Large & Medium & Large & Medium & Large & Small \\
\hline FAB Member & No & No & No & FAB UK-IR & NEFAB & FABEC & No \\
\hline
\end{tabular}

\section{Process Assessment and Appraisal between ATC-Service Providers}

In reference to research tasks a specific maturity level analysis and measurement method for ATC Maintenance Service Provision is developed. The results for each analysed ATC Provider are summarized into a specific SWOT Analysis and descriptive part. It should be mentioned that NATS and LVF are not 
able to deliver the requested information, due to high time effort. The analysis tasks are structured into a 4-step-approach:

1. Step Structuring of ATC Maintenance Process Information based on a set of cirteria.

2. Step Performing a rating assessment of utilization by theoretical methods.

3. Step Comparison and evaluation of implemented Key Performance Indicator System (KPI).

4. Step ATC Process Maturity Assessment based on principle of ISO/ IEC 15504 [1-5].

The research goal is to evaluate the ATC organisations from different aspects. It shall be mentioned that all used methods are qualifying methods based on defined attributes in reference to the ISO/IEC 15504 Standard. The ISO/IEC 15504 concept is transformed to ATC evaluation specifics and KPIs. The research contains all detailed information like, selection parameter, criteria catalogue for analysis, conspectus of interviews, SWOT analysis and detailed conclusions. Due to the limits of article the results can be only summarized.

\section{Step 1: Results of ATC Maintenance Process Analysis}

LGS, Latvia [9]

$\rightarrow$ Maintenance process follows a strong practical orientation and is system oriented

$\rightarrow$ The maintenance guideline and procedures are described textual on system level. The maintenance is technical system oriented.

$\rightarrow$ The Maintenance process is certified by the national authority and by the ISO 2001 standard.

$\rightarrow$ Usual technical metrics are collected manually.

FAA, United States of America [10, 14-16]

$\rightarrow$ The delivered documents have a top down approach, started from general maintenance philosophy to maintenance guidelines to detail system related maintenance handbooks.

$\rightarrow$ Based on best practice level.

$\rightarrow$ The maintenance is system/subsystem /equipment oriented; includes logistics support.

$\rightarrow$ FAA used own National standards and definition, which are not conforming to the ITIL Standard understanding.

$\rightarrow$ Metrics are reflecting technical parameters.

NAV Canada, Canada [11, 17-19]

$\rightarrow$ The maintenance is strongly process oriented. The Technical Operation and Maintenance is not only technical system oriented, but also includes the quality, safety management, finance and training processes.

$\rightarrow$ Maintenance also includes logistics support.

$\rightarrow$ Definitions of services are only fractional. The ITIL standard is implemented into the Technical Operation of Nav Canada partly.

$\rightarrow$ Maintenance is strongly practical orientated on National and ISO Standard.

$\rightarrow$ Service Level has been only mentioned. Special SLA process is not designed.

$\rightarrow$ Usual technical, finance and other management metrics are defined and reported.

$\rightarrow$ Nav Canada has a clear direction decision, which is presented into the following mind map (Figure 3).

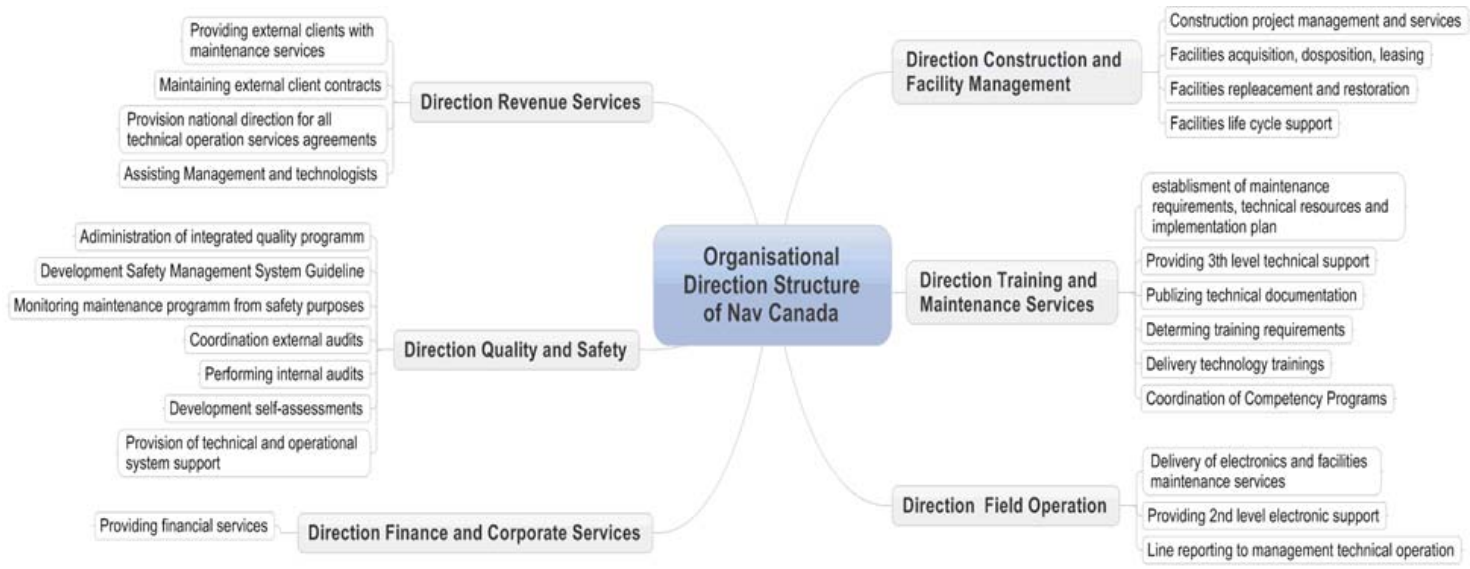

Figure 3. Direction Structure of Nav Canada 
DFS, Germany $[12,22-26]$

$\rightarrow$ The Maintenance is process and service oriented. Services and End-to-End Services are partly implemented.

t The maintenance description and process flow charts based on best practise level, a process or service modelling is not available, processes are not simulated.

$\rightarrow$ The maintenance process is described via a standard structure by process overview and process flow chart including textual description.

$\rightarrow$ A Service Level Management is implemented and in practical use.

$\rightarrow$ The service levels are differentiated into various levels and sub-levels, which are not conform to market and ITIL understanding.

$\rightarrow$ The maintenance process is conforming to ISO, National and SES II standards. The Maintenance Process includes quality, safety management, finance and training processes.

$\rightarrow$ Maintenance process includes also logistics and calibration services.

$\rightarrow$ The DFS Maintenance Process is well processed and partly service-oriented and arranged on different levels of details. The Maintenance is based on the best practice level and is defined by the process flow charts and the detailed description.

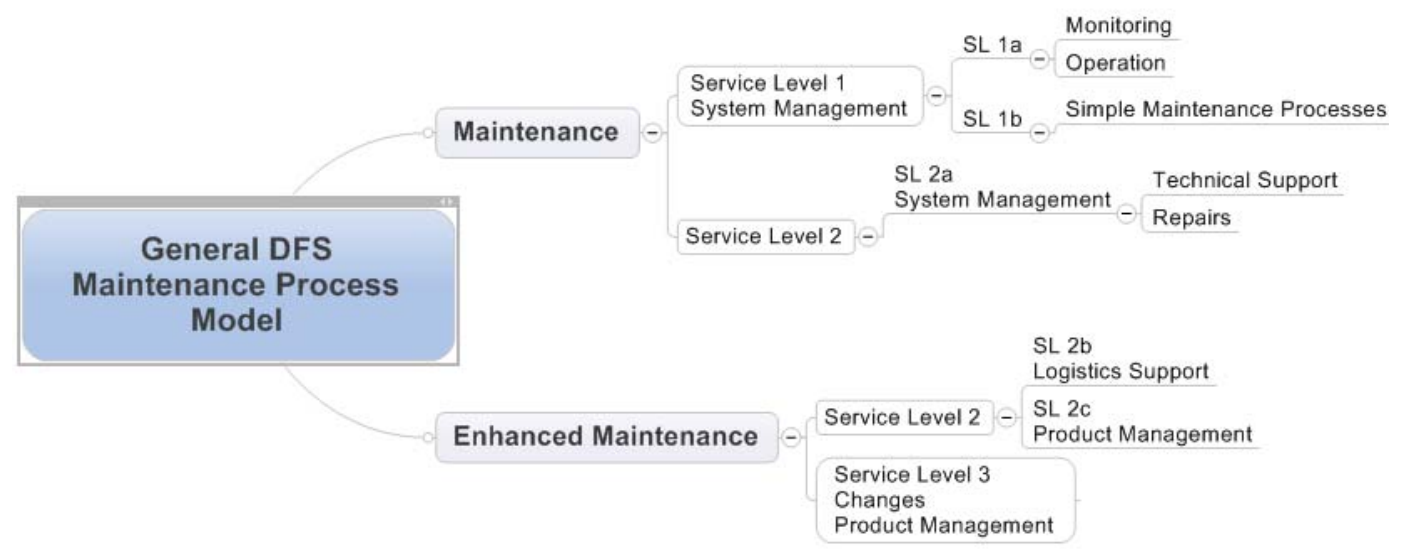

Figure 4. Overview of DFS Maintenance Process Model

TTC, Germany [13]

$\downarrow$ TTC is a specialised Company to deliver ATC controller services for Regional Tower Location and is working into a specific low cost market segment.

+ TTC uses completely the DFS technical support and maintenance infrastructure and has integrated the DFS processes.TTC is able to generate synergies and to purchases completely the technical support and maintenance services from an ATC service provider (DFS).

$\rightarrow$ The TTC impact to DFS and their process landscape is low.

$\rightarrow$ Due to this sourcing strategy of TTC and DFS have the same standardized level of processes and services. Has no own maintenance process and technical services.

Providers:

The following Table 2 describes the summarized appraisal between the researched ATC Service

Table 2. Assessment of Maintenance Process based on the document review

\begin{tabular}{|l|l|l|l|l|}
\hline \multicolumn{1}{|c|}{$\begin{array}{c}\text { Appraisal } \\
\text { Criteria }\end{array}$} & \multicolumn{1}{|c|}{$\begin{array}{c}\text { LGS } \\
\text { Latvia }\end{array}$} & \multicolumn{1}{|c|}{$\begin{array}{c}\text { FAA } \\
\text { USA }\end{array}$} & \multicolumn{1}{c|}{$\begin{array}{c}\text { Nav } \\
\text { Canada }\end{array}$} & \multicolumn{1}{c|}{$\begin{array}{c}\text { DFS } \\
\text { Germany }\end{array}$} \\
\hline $\begin{array}{l}\text { Sourcing of } \\
\text { Maintenance } \\
\text { Process }\end{array}$ & $\begin{array}{l}\text { Maintenance is in-sourced } \\
\text { and part of LGS, organized } \\
\text { into a separate division, } \\
\text { structured by different } \\
\text { technical requirements } \\
\text { Maintenance }\end{array}$ & $\begin{array}{l}\text { Main part of NAS is in- } \\
\text { sourced by FAA personal } \\
\text { and in addition there are } \\
\text { contractors (outsourced) } \\
\text { Mixed Sourcing Strategy }\end{array}$ & $\begin{array}{l}\text { Maintenance and Technical } \\
\text { Support is in-sourced by } \\
\text { Nav Canada, de-central } \\
\text { Maintenance Centres and } \\
\text { centralized Functions in } \\
\text { Headquarter }\end{array}$ & $\begin{array}{l}\text { Maintenance and Technical } \\
\text { Support is in-sourced by } \\
\text { DFS, outsourced } \\
\text { maintenance of system } \\
\text { supplier, } \\
1^{\text {st }} \text { and 2 2d Service Level is } \\
\text { de-central arranged on } \\
\text { different ACC and TWR } \\
\text { locations and CNS } \\
\text { Maintenance Centres, } \\
3^{\text {rd }} \text { Level Support and } \\
\text { Logistics Support is } \\
\text { centralized into the } \\
\text { Headquarter }\end{array}$ \\
\hline
\end{tabular}




\begin{tabular}{|c|c|c|c|c|}
\hline $\begin{array}{l}\text { Appraisal } \\
\text { Criteria }\end{array}$ & $\begin{array}{c}\text { LGS } \\
\text { Latvia }\end{array}$ & $\begin{array}{l}\text { FAA } \\
\text { USA }\end{array}$ & $\begin{array}{c}\text { Nav } \\
\text { Canada }\end{array}$ & $\begin{array}{c}\text { DFS } \\
\text { Germany }\end{array}$ \\
\hline $\begin{array}{l}\text { Maintenance } \\
\text { Process } \\
\text { Definition }\end{array}$ & $\begin{array}{l}\text { No Process Definition, } \\
\text { Operation is described by } \\
\text { the textual documents for } \\
\text { each special division, the } \\
\text { specific task and roles are } \\
\text { integrated into the technical } \\
\text { teams and into the role } \\
\text { /responsibility of the senior } \\
\text { engineer and the system } \\
\text { engineer }\end{array}$ & $\begin{array}{l}\text { Process - Oriented, } \\
\text { including the service } \\
\text { fragments } \\
\text {-Services are defined by } \\
\text { the national FAA } \\
\text { understanding, they are not } \\
\text { conforming to ITIL }\end{array}$ & $\begin{array}{l}\text { Process - Functional } \\
\text { oriented, } \\
\text { - Processes are described in } \\
\text { detail and in a number of } \\
\text { Process Flow Charts they } \\
\text { are combined with } \\
\text { management information, } \\
\text { Process are classified and } \\
\text { described basing on the } \\
\text { standard structure - } \\
\text { Integrated Approach to the } \\
\text { Business Management }\end{array}$ & $\begin{array}{l}\text { Process - Service - } \\
\text { oriented } \\
\text {-Processes are described in } \\
\text { details, Service Level and } \\
\text { related Task, } \\
\text { Responsibilities are defined } \\
\text { - Maintenance Process } \\
\text { Model exists and is divided } \\
\text { into } 2 \text { levels of } \\
\text { Maintenance - Description } \\
\text { includes tasks, roles, } \\
\text { responsibilities } \\
\text { - Maintenance Process } \\
\text { Model and Process Flow } \\
\text { Charts also include the } \\
\text { needed pre-service } \\
\text { provision } \\
\text { - Process Metrics and KPIs } \\
\text { are defined and measured }\end{array}$ \\
\hline $\begin{array}{l}\text { Maintenance } \\
\text { Process } \\
\text { Orientation } \\
\end{array}$ & System - Oriented & Process - Oriented & $\begin{array}{l}\text { Process / Functional - } \\
\text { Oriented }\end{array}$ & Process/Service - Oriented \\
\hline $\begin{array}{l}\text { Level of } \\
\text { Standardization }\end{array}$ & $\begin{array}{l}\text { Best Practice Level } \\
\text { approved by national } \\
\text { Authority (CAA } \\
\text { Certification) and ISO } \\
\text { 2000 Certification }\end{array}$ & $\begin{array}{l}\text { Best Practice Level } \\
\text { conform to the national US } \\
\text { FAA Standards, US } \\
\text { Government Manual }\end{array}$ & $\begin{array}{l}\text { Best Practice Level and } \\
\text { International } \\
\text { Standardization by } \\
\text { ISO 9001:2000, } \\
\text { ISO 14001:2004 }\end{array}$ & $\begin{array}{l}\text { Best Practice Level } \\
\text { approved by the National } \\
\text { Authority BAF, } \\
\text { Standardization by } \\
\text { ISO 9001:200, SES II }\end{array}$ \\
\hline $\begin{array}{l}\text { Level of Process } \\
\text { Implementation }\end{array}$ & $\begin{array}{l}\text { Verbal Process Description } \\
\text { and definition of the tasks / } \\
\text { roles by senior and system } \\
\text { engineer }\end{array}$ & $\begin{array}{l}\text { Process Modelling } \\
\text { (more detailed information } \\
\text { is not available) }\end{array}$ & $\begin{array}{l}\text { Detailed Process Structure, } \\
\text { Process Description, } \\
\text { Process Flow Charts } \\
\text { combined with KPI+ } \\
\text { Management Description }\end{array}$ & $\begin{array}{l}\text { Maintenance Process } \\
\text { Model including 2-level } \\
\text { Process Flow Chart } \\
\text { combined with the } \\
\text { additional textual } \\
\text { description and KPI } \\
\end{array}$ \\
\hline $\begin{array}{l}\text { Level of } \\
\text { Cooperation / } \\
\text { Partnership }\end{array}$ & No cooperation & No cooperation & No cooperation & $\begin{array}{l}\text { Cooperation inside the } \\
\text { FABEC with other ANSP, } \\
\text { performing regular } \\
\text { Benchmarking }\end{array}$ \\
\hline $\begin{array}{l}\text { Service Level } \\
\text { Definition }\end{array}$ & No & $\begin{array}{l}\text { Different service level } \\
\text { implemented: } \\
-1^{\text {st }} \text { Level Field } \\
\text { Maintenance Support } \\
-2^{\text {nd }} \text { Level Technical } \\
\text { Support Office and } \\
\text { Engineering } \\
\text {-Depot Service, central } \\
\text { FAA Logistics Center } \\
\text { FAA defines } 2 \text { Service } \\
\text { Level Policy, service } \\
\text { management and Service } \\
\text { Level Management are not } \\
\text { mentioned }\end{array}$ & $\begin{array}{l}\text { General Process Structure: } \\
\text { - Construction } \\
\text { - Finance } \\
\text { - Publication } \\
\text { - Supporting } \\
\text { Mention of Service Level: } \\
\text { - } 2^{\text {nd }} \text { Level Electronic } \\
\text { Support and Maintenance } \\
\text { - 3rd Level Technical } \\
\text { Support } \\
\text { Service Levels are } \\
\text { mentioned fragmentally } \\
\text { and not ITIL conformed }\end{array}$ & $\begin{array}{l}\text { - Strong Implementation of } \\
\text { SLM } \\
\text {-Definition of the detailed } \\
\text { Service Level based on } \\
\text { DFS-own national under- } \\
\text { standings (not conformed } \\
\text { or only partly conform to } \\
\text { ITIL and market under- } \\
\text { standing) } \\
\text { Overview of detailed SL } \\
\text { Definition refer to figure } \\
\text { B4.2, SL: 1-a, 1-b / } \\
\text { SL 2-a, 2-b, 2-c / SL } 3 \\
\text { - Detailed Task Description } \\
\text { for each SL }\end{array}$ \\
\hline $\begin{array}{l}\text { Maintenance } \\
\text { Organisation }\end{array}$ & Central located & $\begin{array}{l}\text { Central / De-central } \\
\text { Technical Operations are } \\
\text { the Service Units within } \\
\text { the ATC Organization, } \\
1^{\text {st }} \text { Level Field } \\
\text { Maintenance Support is de- } \\
\text { centralized } \\
2^{\text {nd }} \text { Level Engineering } \\
\text { Support, Depot Service is } \\
\text { centralized }\end{array}$ & $\begin{array}{l}\text { Central / De-central } \\
\text { Headquarter and regional } \\
\text { on-site Management : } \\
\text { - central: } \\
\text { Maintenance development, } \\
\text { approval and directives } \\
\text { - Regional: Implementation } \\
\text { and operation }\end{array}$ & $\begin{array}{l}\text { Central / De-central } \\
\text { Central on Headquarter: } \\
\text { SL 2c, } 3 \text { Product } \\
\text { Management and SL 2b } \\
\text { Logistics } \\
\text { De-central on location: } \\
\text { SL 1a,b and 2a }\end{array}$ \\
\hline
\end{tabular}




\begin{tabular}{|c|c|c|c|c|}
\hline $\begin{array}{l}\text { Appraisal } \\
\text { Criteria }\end{array}$ & $\begin{array}{c}\text { LGS } \\
\text { Latvia }\end{array}$ & $\begin{array}{l}\text { FAA } \\
\text { USA }\end{array}$ & $\begin{array}{c}\text { Nav } \\
\text { Canada }\end{array}$ & $\begin{array}{c}\text { DFS } \\
\text { Germany }\end{array}$ \\
\hline $\begin{array}{l}\text { Level of Process } \\
\text { Documentation }\end{array}$ & $\begin{array}{l}\text { LGS Document DI TD } 01 / 2 \\
\text { is the general instruction of } \\
\text { technical maintenance, this } \\
\text { document is a general } \\
\text { management textual } \\
\text { description on best practice } \\
\text { level, the maintenance } \\
\text { arranged on the system } \\
\text { orientation, the next level } \\
\text { of documentation is } \\
\text { technical proceedings from } \\
\text { the Soviet Union Time } \\
\text { Period, which are approved } \\
\text { by Latvian National Civil } \\
\text { Aviation Agency }\end{array}$ & $\begin{array}{l}\text {-FAA maintenance } \\
\text { processes with KPI usual in } \\
\text { FAA handbooks are } \\
\text { described, } \\
\text {-Different levels of } \\
\text { documentation: } \\
\text { 1.General Maintenance } \\
\text { Handbook } \\
\text { 2. over } 6000 \text { series of the } \\
\text { Equipment Handbooks } \\
\text { 3. National Airspace } \\
\text { System Maintenance } \\
\text { Policy }\end{array}$ & $\begin{array}{l}\text { Structured Maintenance } \\
\text { Documentation: } \\
\text { 1. General Policy and } \\
\text { Standards } \\
\text { 2. Schedules and } \\
\text { Procedures } \\
\text { 3. Certification, Standard } \\
\text { 4. Training Staff } \\
\text { 5. Quality Evaluation } \\
\text {-Process Descriptions } \\
\text { follow the standard way } \\
\text { - Combination of } \\
\text { Maintenance Process to } \\
\text { Business Finance } \\
\text { Alignment } \\
\text { - Complete Process Flow } \\
\text { Chart System with KPIs } \\
\text { and trend analysis } \\
\end{array}$ & $\begin{array}{l}\text { Structured Maintenance } \\
\text { Documentation: } \\
\text {-DFS Company } \\
\text { Operational Guideline } \\
\text { - Process Model / } \\
\text { Overview } \\
\text { - Process Description and } \\
\text { Flow Charts } \\
\text { - Working Procedures } \\
\text { - Service Management } \\
\text { Handbook } \\
\text { - Service Level } \\
\text { Agreements }\end{array}$ \\
\hline $\begin{array}{l}\text { Level of } \\
\text { Automation }\end{array}$ & $\begin{array}{l}\text { No automation, defined } \\
\text { technical metrics (refer to } \\
\text { annex B1) and incidents } \\
\text { were collected manually, } \\
\text { statistically analysed and } \\
\text { reported on the technical } \\
\text { level }\end{array}$ & $\begin{array}{l}\text { Remote Maintenance } \\
\text { Monitoring (RMM) is an } \\
\text { automated system and } \\
\text { performance monitoring, } \\
\text { using different data basis }\end{array}$ & $\begin{array}{l}\text { Computerised Maintenance } \\
\text { Management System as } \\
\text { Work Order System } \\
\text { Storing of Maintenance } \\
\text { data and activities, manage } \\
\text { inventory, resources and } \\
\text { maintenance plan } \\
\text { (MAXIMO) }\end{array}$ & $\begin{array}{l}\text { Automated and } \\
\text { Computerised System } \\
\text { Monitoring and Control } \\
\text { (CMMC), Maintenance } \\
\text { Management and } \\
\text { Coordination Tool } \\
\text { (KOSYS), Work Flow and } \\
\text { Know - How Data Base } \\
\text { Tool (SASS) and Service } \\
\text { Management and } \\
\text { Reporting Tool, automated } \\
\text { tools with different } \\
\text { interface to central SAP } \\
\text { tool }\end{array}$ \\
\hline
\end{tabular}

\section{Step 2: Rating Utilization Assessment of Theoretical Methods and Instruments}

Basing on the performed theoretical research of methods and instruments in the following evaluation the utilization level of theoretical methods and instruments will be compared by the researched ATC organisations for implementation of the Maintenance Process and Service Orientation.

Table 3. Rating utilization assessment of theoretical methods and instruments at researched ATC organisations

\begin{tabular}{|c|c|c|c|c|c|}
\hline Theoretical Methods/Instruments & LGS & FAA & $\begin{array}{c}\text { NAV } \\
\text { Canada }\end{array}$ & DFS & TCC \\
\hline Economic Indicator Models & $\mathrm{N}$ & $\mathrm{N}$ & $\mathrm{N}$ & $\mathrm{N}$ & $\mathrm{N}$ \\
\hline COBIT 2000 Systematic & $\mathrm{N}$ & $\mathrm{N}$ & $\mathrm{N}$ & $\mathrm{N}$ & $\mathrm{N}$ \\
\hline Mathematical Decision Making & $\mathrm{N}$ & $\mathrm{N}$ & $\mathrm{N}$ & $\mathrm{N}$ & 0 \\
\hline Decision Priority Matrix Model & $\mathrm{N}$ & $\mathrm{N}$ & $\mathrm{N}$ & $\mathrm{N}$ & 0 \\
\hline Input - Output Model & $\mathrm{N}$ & $\mathrm{P}$ & $\mathrm{F}$ & $\mathrm{F}$ & 0 \\
\hline Data Process Model & $\mathrm{N}$ & $\mathrm{N}$ & $\mathrm{P}$ & $\mathrm{L}$ & 0 \\
\hline Structured Process Description & $\mathrm{N}$ & $\mathrm{L}$ & $\mathrm{F}$ & $\mathrm{F}$ & 0 \\
\hline Process Flow Model & $\mathrm{N}$ & $\mathrm{N}$ & $\mathrm{F}$ & $\mathrm{F}$ & 0 \\
\hline Business Modelling & $\mathrm{N}$ & $\mathrm{N}$ & $\mathrm{P}$ & $\mathrm{P}$ & 0 \\
\hline Service Modelling & $\mathrm{N}$ & $\mathrm{N}$ & $\mathrm{P}$ & $\mathrm{L}$ & 0 \\
\hline Process Model Simulation & $\mathrm{N}$ & $\mathrm{N}$ & $\mathrm{N}$ & $\mathrm{N}$ & 0 \\
\hline Mathematical Time State System & $\mathrm{N}$ & $\mathrm{N}$ & $\mathrm{N}$ & $\mathrm{N}$ & 0 \\
\hline Graphs Theory & $\mathrm{N}$ & $\mathrm{N}$ & $\mathrm{P}$ & $\mathrm{P}$ & 0 \\
\hline Process Maturity Evaluation & $\mathrm{N}$ & $\mathrm{N}$ & $\mathrm{P}$ & $\mathrm{P}$ & 0 \\
\hline ISO Standard 9000:2001 & $\mathrm{F}$ & $\mathrm{N}$ & $\mathrm{F}$ & $\mathrm{F}$ & $\mathrm{N}$ \\
\hline ISO Standard 20000 & $\mathrm{~N}$ & $\mathrm{~N}$ & $\mathrm{~N}$ & $\mathrm{~N}$ & $\mathrm{~N}$ \\
\hline ITIL de-facto Standard & $\mathrm{N}$ & $\mathrm{N}$ & $\mathrm{P}$ & $\mathrm{P}$ & $\mathrm{N}$ \\
\hline
\end{tabular}


Qualified level of utilisation classification is conforming to the rating process attributes of International Standard ISO/IEC 15504-2, chapter 5.7 [3]:

0 Not Rated.

$\mathrm{N}$ Not Achieved, little or no evidence of defined assessed criteria 0 to $15 \%$.

$\mathrm{P}$ Partially achieved, there is some evidence on theoretical approach, defined attribute and fragments in assessed process implemented $>15 \%$ to $50 \%$.

L Largely achieved, there is an evidence of a structured systematic approach, significant achievement, defined attributes are implemented, monitored and controlled in the assessed process $>50 \%$ to $85 \%$.

F Fully achieved, there is a complete evidence and systematic approach, full achievement, all defined attributes are implemented, monitored and controlled in the assessed process $>85 \%$ to $100 \%$ achievement.

The coloured marker identifies the general fulfilment of the implemented theoretical methods and instruments and the main qualitative differences between the ATC organisations.

\section{Step 3: Comparison and Qualified Evaluation of the Implemented KPI System}

Comparison of used metrics of the researched ATC organisation is based on the delivered information and is described into the following overview.

Table 4. Comparison of used Metrics by the researched ATC organisations

\begin{tabular}{|c|c|c|c|c|c|}
\hline $\begin{array}{c}\text { General } \\
\text { Air Transport } \\
\text { System } \\
\text { Metrics }\end{array}$ & $\begin{array}{c}\text { LGS } \\
\text { Metrics System }\end{array}$ & $\begin{array}{c}\text { FAA } \\
\text { Metrics System }\end{array}$ & $\begin{array}{c}\text { Nav Canada } \\
\text { Metrics System }\end{array}$ & $\begin{array}{c}\text { DFS } \\
\text { Metrics System }\end{array}$ & $\begin{array}{c}\text { TTC } \\
\text { Metrics System }\end{array}$ \\
\hline $\begin{array}{l}\text { Safety Security } \\
\mathrm{W}_{\text {ATCpart (1) }}\end{array}$ & $\begin{array}{l}\text { Safety } \\
\text { Coefficients }\end{array}$ & Nil & Nil & $\mathrm{N}_{\mathrm{STU}}$ & Nil \\
\hline $\begin{array}{l}\text { Cost Effects } \\
\mathrm{R}_{\text {ATCfee (2) }} \\
\mathrm{R}_{\text {ATCEnrouteFee (4) }} \\
\mathrm{t}_{\text {NationalUnitRate (5) }} \\
\text { E }_{\text {RouteExtensions (6) }}\end{array}$ & Nil & Nil & Nil & $\begin{array}{l}\text { Cost Performance } \\
\text { Index } \\
\text { Productiveness } \\
\text { Resource Capacity } \\
\text { Utilization }\end{array}$ & Nil \\
\hline $\begin{array}{l}\text { Service Technical } \\
\text { Quality } \\
\mathrm{A}_{\text {operational (8) }} \\
\mathrm{A}_{\text {technical (9) }} \\
\mathrm{T}_{\text {MTTS }}\end{array}$ & $\begin{array}{l}\mathrm{P}_{\text {outage }} \\
\text { Availability } \\
\text { - technical } \\
\text { Reliability } \\
\mathrm{T}_{\text {operationOutages }} \\
\mathrm{N}_{\text {outages }} \\
\mathrm{N}_{\text {ControllerCompliants }} \\
\text { Robustness }\end{array}$ & $\begin{array}{l}\text { Trend Analysis } \\
\text { Key Performance } \\
\text { Parameter }\end{array}$ & Nil & $\begin{array}{l}\text { Availability } \\
\text { - technical } \\
\text { - operational } \\
\text { Availability Index } \\
\text { Operational } \\
\text { Service } \\
\text { Availability } \\
\text { Reaction Time } \\
\text { Recovery Time }\end{array}$ & Nil \\
\hline $\begin{array}{l}\text { Environmental } \\
\text { Factors } \\
\mathrm{R}_{\text {RouteExtensions (11) }}\end{array}$ & Nil & Nil & Nil & Nil & Nil \\
\hline
\end{tabular}

Only two ATC organisations reflect the ascertained and detailed metrics. Other ATC organisations demonstrate only the general usage of the performance parameter. It was detected that metric understanding is different. The research of metrics is to define the ascertained parameter for calculation of technical / process / service / business process evaluation. In reference to Table 4, it is visible that a common usage of parameter is not given, a standard implementation of the certain KPI system into the ATC praxis is not given up to now. Especially the implementation of the Service related KPIs is in general not realized.

\section{Step 4: Process Maturity Assessment for the ATC-Maintenance Process}

The Process Maturity Assessment is based on the principles of ISO/ IEC Standard 1504 [2-6] and the practical experience of the Company Hisolutions [7-8]. This procedure is adapted to ATC purposes. It should be noted that only the Nav Canada and DFS were able to deliver the detailed process description 
and process flow charts. So the following process maturity assessment is based only on two ATC process models by Nav Canada and DFS. The assessment scope is defined by the following parameters:

- To assess the maintenance process objectives.

- To assess the detailed level and quality of the maintenance process modelling.

- To assess the maintenance process with business and management process aspects.

- To assess the methods of process flow charts and descriptions.

- To assess theoretical and practical usage of the maintenance process flow.

- To assess the defined KPI parameter of the process controlling.

- To give up a qualified ATC process rating.

The ISO/ IES standard 15504 helps to give a structured approach for the assessment of the processes, which are adapted to the ATC maintenance process, gives a process improvement and provides an objective benchmark of the ATC maintenance process. The assessment steps are described on Figure 3 and they illustrate the adaptation of the assessment process for the ATC Maintenance Process. In reference to ISO/IEC standard 15504-2 performing an assessment is defined as follows: "The purpose of the process assessment is to understand the capability of the processes implemented by an organization. As result of process assessment

a) information and data that characterize the processes assessed are determined;

b) the extent to which the processes achieve the process purpose is determined." [3]

From this normative components the following process criteria based on the mentioned standard, can be derived for the ATC Maintenance and Service Model. The assessment process activities are tailored and redesigned to the ATC specifics. The following Table 5 is derived basing on ISO / IEC Standard 15504-3 and describes the developed ATC specifics.

Table 5. Process Capability Matrix of ATC Maintenance and Service Process Maturity

\begin{tabular}{|c|c|c|c|}
\hline \multicolumn{4}{|c|}{ Process Capability Matrix of ATC Maintenance and Service Process Maturity } \\
\hline \multicolumn{3}{|c|}{ Maturity Assessment Criteria on ISO/IEC 15540-4 } & \multirow[t]{2}{*}{ ATC Specific Derivation of Process Attributes } \\
\hline $\begin{array}{l}\text { COBIT } \\
\text { Maturity } \\
\text { Level }\end{array}$ & $\begin{array}{l}\text { Rating } \\
\text { Fulfillment }\end{array}$ & $\begin{array}{l}\text { General Process } \\
\text { Attributes }\end{array}$ & \\
\hline $\begin{array}{l}\text { ML 0 } \\
\text { Incomplete } \\
\text { Process }\end{array}$ & & & Service Process is not implemented, not defined, not realized \\
\hline \multirow[t]{2}{*}{$\begin{array}{l}\text { ML } 1 \\
\text { Performed } \\
\text { Process }\end{array}$} & & & Processes mostly defined and implemented \\
\hline & L or F & Process Performance & $\begin{array}{l}\text { PA 1.1 Service Processes are defined and the main processes are completed } \\
\text { PA1.2 Process Landscape exists }\end{array}$ \\
\hline \multirow[t]{4}{*}{$\begin{array}{l}\text { ML } 2 \\
\text { Managed } \\
\text { Process }\end{array}$} & & & Processes are completely implemented and managed \\
\hline & $\mathrm{F}$ & Process Performance & $\begin{array}{l}\text { PA 2.1 Process KPI and Metrics are identified } \\
\text { PA 2.2 Process Performance is defined and monitored } \\
\text { PA 2.3 Process Resources, Roles and Tasks are identified and available }\end{array}$ \\
\hline & L or F & $\begin{array}{l}\text { Management } \\
\text { Performance }\end{array}$ & $\begin{array}{l}\text { PA 2.4 Process KPI and Metrics are identified } \\
\text { PA 2.5 Process Performance is defined and monitored } \\
\text { PA 2.6 Process Interfaces are identified and managed }\end{array}$ \\
\hline & Lor F & $\begin{array}{l}\text { Work Product } \\
\text { Management }\end{array}$ & $\begin{array}{l}\text { PA 2.7 Process Requirements and Metrics are defined } \\
\text { PA 2.8 Documentation and Controlling Process Requirements identified } \\
\text { PA 2.9 Inputs and Outputs are managed, reviewed based on requirements }\end{array}$ \\
\hline
\end{tabular}




\begin{tabular}{|c|c|c|c|}
\hline \multicolumn{3}{|c|}{ Maturity Assessment Criteria on ISO/IEC 15540-4 } & \multirow[t]{2}{*}{ ATC Specific Derivation of Process Attributes } \\
\hline $\begin{array}{l}\text { COBIT } \\
\text { Maturity } \\
\text { Level }\end{array}$ & $\begin{array}{l}\text { Rating } \\
\text { Fulfillment }\end{array}$ & $\begin{array}{l}\text { General Process } \\
\text { Attributes }\end{array}$ & \\
\hline \multirow[t]{3}{*}{$\begin{array}{l}\text { ML } 3 \\
\text { Established } \\
\text { Process }\end{array}$} & $\mathbf{F}$ & & $\begin{array}{l}\text { Processes are implemented, managed, controlled and capable basing } \\
\text { on the defined requirements and measured by defined metrics. }\end{array}$ \\
\hline & $\mathrm{L}$ or $\mathrm{F}$ & Process Definition & $\begin{array}{l}\text { PA 3.1 All resources and environment are available } \\
\text { PA 3.2 Human Resources and capacities are defined } \\
\text { PA 3.3 Personal is provably competent, educated and regularly tested } \\
\text { PA 3.4 Process data are collected, analysed on effectiveness and suitability } \\
\text { of the Maintenance Process Landscape }\end{array}$ \\
\hline & L or F & Process Deployment & $\begin{array}{l}\text { PA 3.5 Process is deployed in the standard processes } \\
\text { PA 3.6 Level of automation and tool support is partly implemented }\end{array}$ \\
\hline \multirow[t]{3}{*}{$\begin{array}{l}\text { ML } 4 \\
\text { Predictable } \\
\text { Process }\end{array}$} & & & $\begin{array}{l}\text { Process operates basing on the given parameter, metrics and process } \\
\text { requirements; Maintenance Process and Process results are operated } \\
\text { inside the given KPIs }\end{array}$ \\
\hline & L or F & Process Measurement & $\begin{array}{l}\text { PA 4.1 Process includes business / service processes and aspects } \\
\text { PA 4.2 Processes are regularly measured basing on the defined technical, } \\
\text { process and business metrics } \\
\text { PA 4.3 Measurement objectives, elements, proceeding and frequency } \\
\text { are defined in the process description } \\
\text { PA 4.4 Process performance is in correlation to business requirements } \\
\text { PA 4.5 Process measurements are managed, analysed, reported in } \\
\text { accordance with the defined metrics, reported } \\
\text { PA 4.6 Process deployment is in accordance with the process performance }\end{array}$ \\
\hline & L or F & Process Control & $\begin{array}{l}\text { PA 4.7 Process Analysing and Controlling are defined and implemented } \\
\text { PA 4.8 Defined Process KPIs contains the defined control limits for pro- } \\
\text { active process management } \\
\text { PA 4.9 Basing on the regular and active Process controlling corrective tasks } \\
\text { are defined, documented and realized in operation } \\
\text { PA 4.10 Process System is a dynamic controlling system based on the } \\
\text { indications of operation }\end{array}$ \\
\hline \multirow[t]{2}{*}{$\begin{array}{l}\text { ML } 5 \\
\text { Optimising } \\
\text { Process }\end{array}$} & & & $\begin{array}{l}\text { Process is continuously approved, follows the PDCA Cycle, } \\
\text { Maintenance Process contains all technical, business, service, } \\
\text { organizational aspects }\end{array}$ \\
\hline & $\mathrm{L}$ or $\mathrm{F}$ & Process Innovation & $\begin{array}{l}\text { PA 5.1 Process improvement is actively established and supports all the } \\
\text { required business requirements } \\
\text { PA 5.2 Process improvement is actively used for the dynamic process } \\
\text { performance and establishment of the different process } \\
\text { performance level is based on the required service levels } \\
\text { PA 5.3 Regular Process and Data analysing is performed in correlation } \\
\text { to existing market standards, best practice and benchmarks } \\
\text { PA 5.4 Process is under regular improvement process plan based on } \\
\text { new technologies and methods } \\
\text { PA 5.5 Process Management, Controlling and Improvement is }\end{array}$ \\
\hline
\end{tabular}




\section{Results of Process Maturity Assessment of ATC Organization}

\section{NAV Canada}

The maintenance process was evaluated by review of delivered documents and process description [17-19]. In general the Nav Canada Maintenance process is performed on detailed process flow charts on UML; is divided into defined process bundles. These bundles are break down to detailed processes. So the maintenance process of Nav Canada is described and tailored into 44 different processes and flow charts. The detailed process is described by standard approach:

- Description via process flow charts;

- Each Process Flow Chart is described by the following textual description via tables.

\begin{tabular}{|l|l|l|l|l|l|l|}
\hline $\begin{array}{l}\text { Business } \\
\text { Requirements }\end{array}$ & Inputs & Outputs & References & $\begin{array}{l}\text { Work } \\
\text { Instruction }\end{array}$ & Hazards \\
\hline Risks & Mitigation & Records & Metrics & Likelyhood & $\begin{array}{c}\text { Technical } \\
\text { Operation } \\
\text { Information }\end{array}$ \\
\hline
\end{tabular}

This kind of process flow description gives an overview of detailed maintenance process. Each process flow is described in detail by a number of detailed processes. Several times the mentioned additional textual description is empty (Work Instruction Listings, Mitigation, Hazards). Also the quality of metric definition and business requirements is sometimes insufficient. In general the type of process presentation gives a professional overview combined with needed management information. The analysis of Nav Canada Maintenance Process is illustrated in the following diagrams. Process modelling is focusing of process flow charts and description, without of real modelling and process simulation. General lack of process modelling is the missing of process performance metrics and their measurements. Process KPIs in general are not defined. The different process bundles and detailed processes are developed on same standard level. The process flow chart description from quality point of view sometimes is different. The same flow charts are described superficial (Technical Operation Accounts Payable Invoice Process, Technical Operations Capital Project Approval Process), other flow chart describes the processes in detail (Competency Process, Contract Services/ Maintenance and Space). So the level of detailing is not homogeneously. In reference to the ISO / IEC assessment chart it is not possible to define a clear reached level of process maturity profile. Fact is that the Nav Canada maintenance process is fulfilling completely the requirements of maturity level ML1 and mostly parts of ML 2 . In level ML 2 the main lack of process modelling are the missing process metrics and performance measurements itself. The process attributes reached an overall standard level, which is presented on Figure 5. The diagram presents the degree of fulfilment for each defined maturity level.

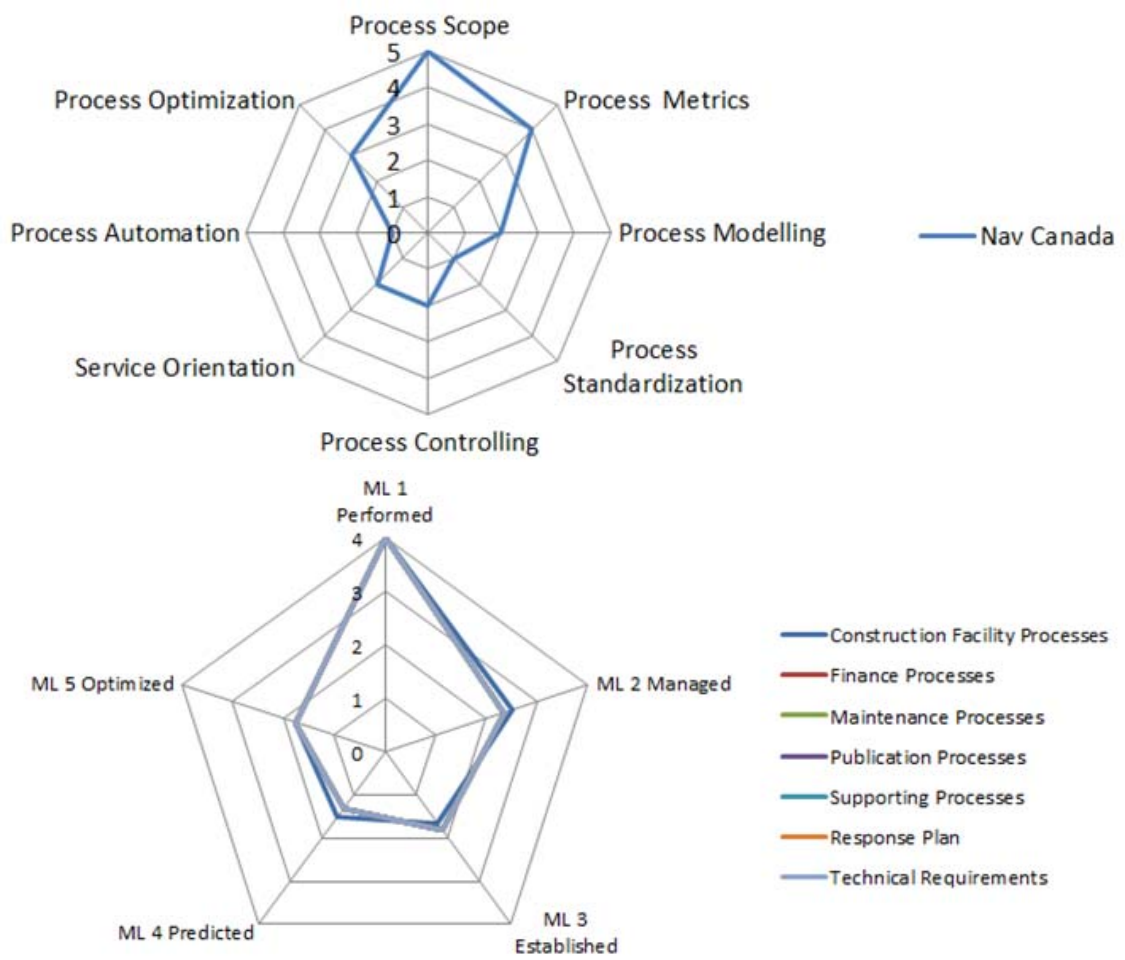

Figure 5. Nav Canada ATC Maintenance Process Maturity Assessments 


\section{DFS ACC Bremen}

The DFS maintenance process for ACC Bremen was assessed based on the delivered process description documents, interview and additional management documents [12, 22-25]. The DFS maintenance process is different from Nav Canada. The DFS starts to model a Maintenance Process Landscape as an overview. Starting from this process landscape the DFS is modelling into the next level of detail. The number of maintenance processes is not as high as at Nav Canada. Due to this by proceeding the process the modelling is more complex. The proceeding of DFS maintenance process modelling based on process flow charts on UML and detailed process description. The Figure 6 presents the reached level of process modelling attributes. In difference to Nav Canada the Input/Output, process interfaces, customers, external suppliers and partners are defined in general for the DFS process landscape. Also the process and product metrics are defined. The process landscape is describing the main maintenance process components including references of entry and existing points to other processes. Each detailed process is developed by process flow chart and includes a textual description in structured table form. This description table depicts all process steps in detail, including roles and responsibilities, applicable and approval documents. The quality of metric definitions is in general and not in detail to the related process step. The combination of process flow chart and structured description gives a sophisticated information basis of related maintenance process. Management information about business requirements, work instructions, hazards, risks, and such, are missing completely. Due to higher level of process complexity the process flow chart handling is not quite sufficient as Nav Canada. In comparison to the defined process maturity level the following diagram shows the degree of ML fulfilments. The level of detail description is homogeneously and has the same standard over the complete process description. For DFS the same problem was observed, that in reference to the ISO / IEC it was not possible to define a clear reached level of process maturity profile. DFS reached in general the same level as Nav Canada, but in some cases the DFS process modelling is partly reaching higher maturity fragments. DFS maintenance process is fulfilling completely the requirements of maturity level ML1 and largely parts of ML 2. In the same condition the DFS has the major lack of process modelling in missing of process performance and controlling also.
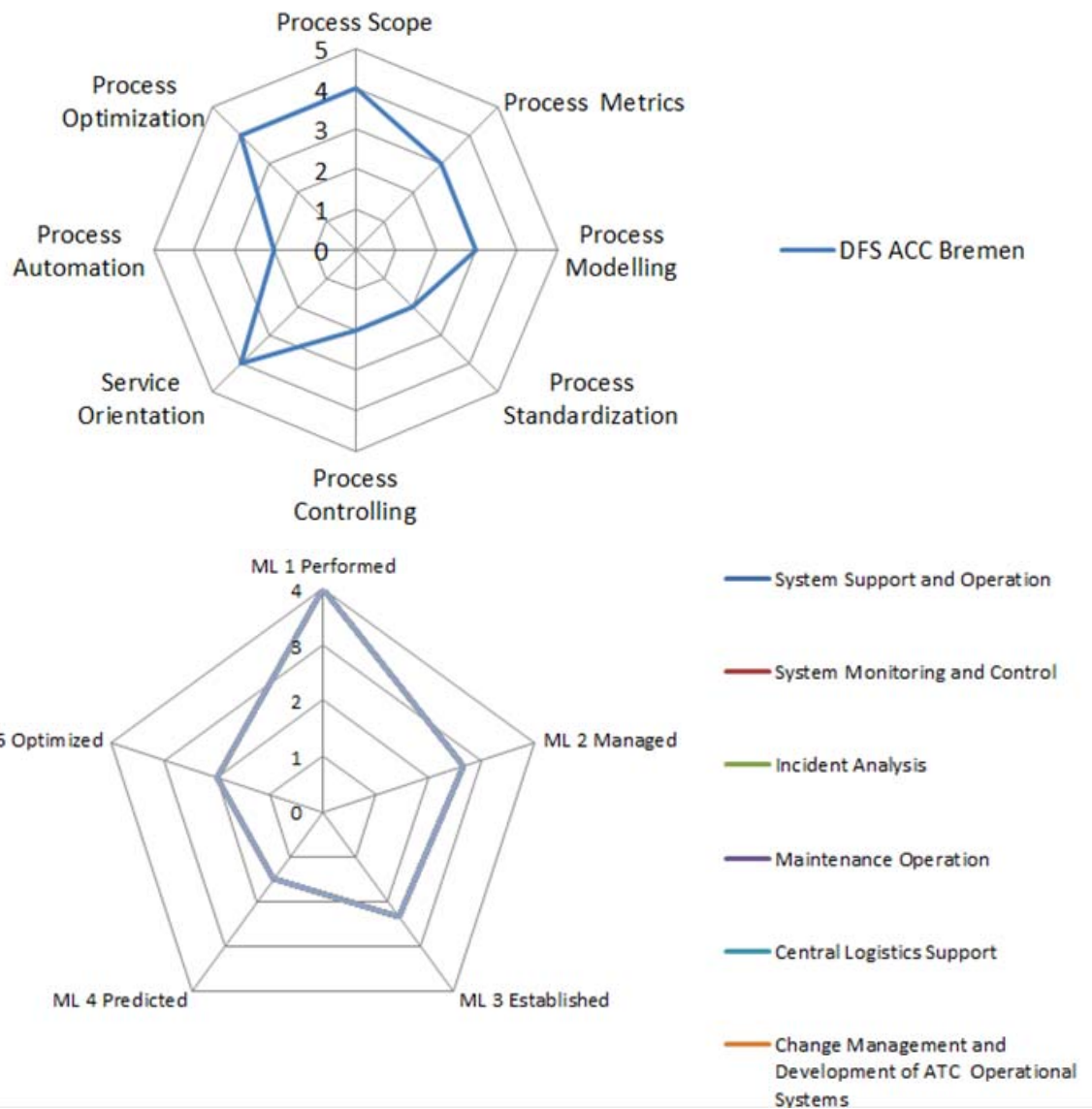

Figure 6. DFS ACC Bremen ATC Maintenance Process Maturity Assessments 


\section{General Results of ATC Maintenance Process Maturity Assessment}

The results of maintenance process maturity assessment are performed between Nav Canada and DFS ACC Bremen process models. In conclusion it can be summarized as follows:

The method and proceeding described in ISO / IEC 15504 is only partly useful, because reached maturity and quality level is different. Both ATC organisations fulfil the ML 1 and most criteria of ML2. In addition the ATC organisations have on different levels and qualities partly fulfils criteria of higher maturity level as well. The following diagram illustrates the different attainment of ISO maturity level based on defined maturity level (ML1-5). Differences can be observed only in ML3 and ML5. The reached levels differ only in minor categories. Based on the defined process attributes the Figure 7 describes the reached process profile in comparison between Nav Canada and DFS.

The process profiles between Nav Canada and DFS differ in all attributes and also in major changes. The following general lacks in process profile attributes has been observed:

- Level of Process Modelling;

- Process Standardization;

- Process Controlling / Process Automation.

The process modelling is performed on textual description and process flow charts. Mathematical process methods and simulations are not used. Process content metrics are used. Process performance metrics are not defined; process performance controlling is not performed. The process modelling proceeding between Nav Canada and DFS is different, so the process description is performed on different level of detail. Nav Canada designed a large number of detailed processes and summarized these detailed processes into bundle. So the detailed process description is not complex. DFS starts from process overview and design a certain number of detailed processes, which are to be described in more complex form. As DFS as NAV Canada design the different maintenance processes on their own national standards and understanding. Terms and conditions are defined by own national understandings (Service Level, System Management, Product Management). International Standards like ITIL are used only partly and only some fragments are used. The terms and definition of ITIL are not used consequently. Service Orientation is implemented only in some fragments, e.g. service level management. Both process modelling of Nav Canada and DFS shows, that Logistics Support Processes and special Calibration Services have a major priority of ATC Maintenance Process Model. That is an ATC specific feature, which was also observed by FAA. Due to the ISO 9001:2000 certification of both ATC organisations have implemented a regular optimisation process based on PCDA-cycle. Indifference the DFS has also implemented a regular company-wide process optimisation program. DFS as single ATC organisation has implemented a regular benchmarking process. DFS performs ATC operational benchmarks with ACC from other ATC companies.

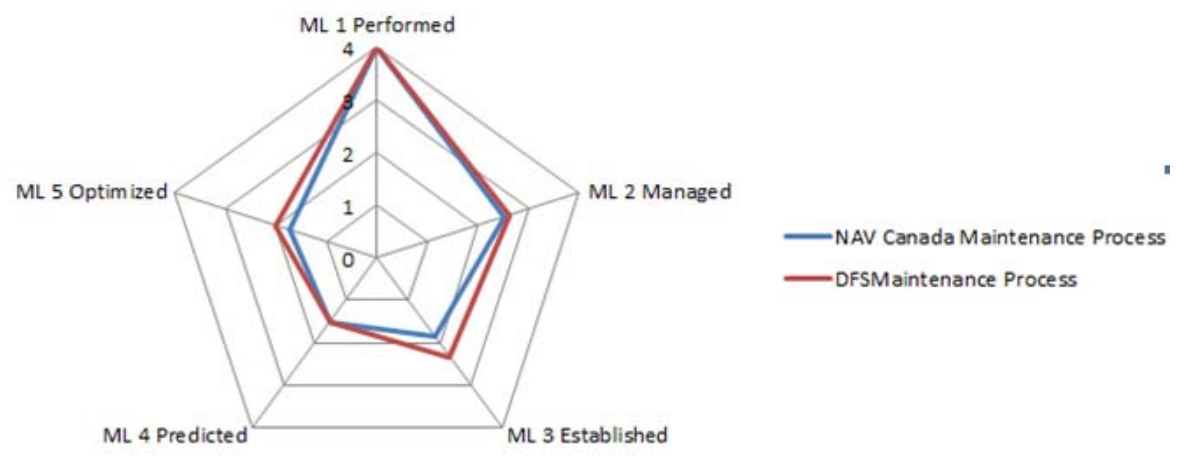

Figure 7. Maturity Level of ATC Maintenance Process Model

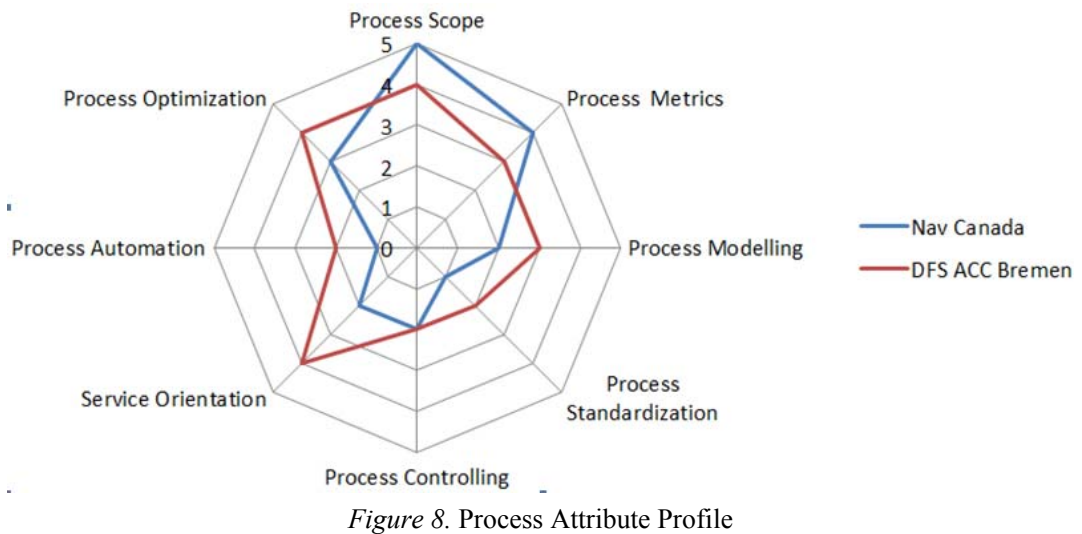




\section{Conclusions}

The maintenance processes of national ATC Organizations are not considered of the mentioned European activities. So each national ATC Organization performed the maintenance process by own rules and experiences. Normally the maintenance process model for ATC systems are the best practice processes that have been developed by own national experiences and own national rules.

$\downarrow \quad$ General definitions of terms, processes and services for the ATC technical support services don't exist. The ATC provider used different definitions and terms. So a "general technical languages" doesn't exist. ATC-providers use their own defined terms and have a national characteristic of understanding for ATC technical support services and their processes.

$\rightarrow$ A standard on European / international level for ATC technical services are not available.

$\rightarrow$ Different parameters are defined on low level only. A set of parameters are defined in different ESARR documents. These parameters reflect only the ATC controller operation side. A complete sequence of parameter derivation is not given. The ATC providers have their own defined parameters for monitoring of ATC technical support. These parameters are derived from practical side and the metric system is on different level of content and reporting. A correlation matrix and relationship between ATC controller parameter and technical support parameter is not given and not described on mathematical basis. Based on the actual level of ATC related parameters to define coherencies and conception of causal relation between the different parameters are not possible. Based on this low level of parameterisation it is not possible to design and build up an overall ATC metric system for all related ATC parts.

$\rightarrow$ A general ATC service and maintenance process model is not available. Also guidelines and criteria for development and design of an ATC service and maintenance process model don't exist.

$\rightarrow$ The described changes for operational ATC on European level have direct impact to the ATC technical service of ATC service provision. The technical maintenance support has changed to a common harmonized technical service orientation. The focus of support should change from technical support to a technical service chain support. The technical support has not to deliver technical support but has to deliver in future a complete technical service delivery and support over complete ATC service chain (end-to-end). The focus should move from technical system view to a service orientation. The implementation of service orientation has major impact not only to the complete ATC process landscape.

Results:

With regards to the actual development of Functional Airspace Blocks (FAB) the ATC operation and the needed technical support should be developed from national side to a multi-national level, because inside of an FAB the ATC processes are to be harmonised between different states and national standards. To develop an ATC technical support service model there is a prerequisite to build up FABs, because the different ATC services shall be delivered by different ATC technical providers for a multinational operated ATC centres or towers. Based on performed ATC maintenance process assessment the following major results were detected:

- It is necessary to develop a general and complete ATC Process Model. There should be developed a Top Down Model for ATM Maintenance \& Service Process Modelling and their derived ATC Process Metrics in relation to the researched specific ATC KPIs.

- Conform to the theoretical research the "General ATM Process Model" and the set of "specific ATC Metrics" should be developed in line to the theoretical methods of process and service modelling.

- The practical results and conclusions of 4-step approaches of ATC Maintenance Process Research by the different researched ATC organisations will have direct usage and impact for the further development of new harmonised ATC Maintenance and Service Model.

\section{References}

1. Stroebel, Martin. (1998). Optimization of Operational Systems based on Business Models. DUV Deutscher Universitäts Verlag. ISBN 3-8244-2107-0

2. International Standard ISO/IEC. (2004). Information technology Process assessment, Part 1: Concepts and vocabulary. 15504-1:2004(E). ( $1^{\text {st }}$ ed.). 2004-11-01.

3. International Standard ISO/IEC. (2003). Information technology Process assessment, Part 2: Performing an assessment. 15504-2:2003(E). (1 $1^{\text {st }}$ ed.). 2003-10-15. 
4. International Standard ISO/IEC. (2004). Information technology Process assessment, Part 3: Guidance on performing an assessment. 15504-3:2004(E). (1 ${ }^{\text {st }}$ ed.). 2004-1-15.

5. International Standard ISO/IEC. (2004). Information technology Process assessment, Part 4: Guidance on use for process improvement and process capability determination. 15504-4:2004(E). ( $1^{\text {st }}$ ed.). 2004-7-01.

6. International Standard ISO/IEC. (2006). Information technology Process assessment, Part 5: An example Process Assessment Model. 15504-4:2004(E). (1 ${ }^{\text {st }}$ ed.). 2006-03-01.

7. Heinrich, T. (2007). Hisolutions AG: Presentation Materials for IT-Process Optimization and ITIL Process Maturity Modelling. Homepage by Hisolutions AG.

8. Heinrich, T. (2007). Presentation Materials Optimization of IT-Processes, Process Availability and Maturity Assessment. Customer Conference Hisolution, BerlinPublishing by Hisolutions AG.

9. Kundler, J., Golosov, V. (2010). Materials of Interview and Questionnaire at Latvijas Gaisa SatiksmeRiga. Maintenance Management Division LGS. Internal Research Working Paper

10. Kundler, J., Walker, J. (2010). Materials of Questionnaire US Department of Transportation at FAA Federal Aviation Administration. Management NAS Policy and Services Planning Team.Washington. Internal Research Working Paper.

11. Kundler, J., Dridell, M.. (2010). Materials of Questionnaire at Nav Canada. Ottawa: Nav Canada, 77 Metcalfe Street, Ottawa CDN Ottawa CDN Service Management. Internal Research Working Paper.

12. Kundler, J., Sunjay, Dussoy. (2010). Materials of Questionnaire at DFS German Air Traffic Control, ACC Center Bremen: Technical Support. Bremen, Germany Internal Research Working Paper.

13. Kundler, J., Koch, Alexander. (2010). Materials of Questionnaire at The Tower Company. TTC Services, Managing Director TTC. Langen, Internal Research Working Paper.

14. U.S. Department of Transportation Federal Aviation Administration National Policy. (2007). Order 6000.30D. Effective Date 9/19/07. Subject: National Airspace System Maintenance Policy. Washington: Publisher FAA AJW-163.

15. U.S. Department of Transportation Federal Aviation Administration National Policy, (00/00/00). Order 6000.15F. Draft, Subject: General Maintenance Handbook for National Airspace System (NAS) Facilities. Washington: Publisher FAA AJW-163.

16. U.S. Department of Transportation Federal Aviation Administration Air Traffic Organization Policy. (2009). Order 6190.19A. Effective date 05/31/2009 Subject: Maintenance of the Automated Radar Terminal System Expansion (ARTS IIE) Washington.

17. NAV CANADA. (2010). Manual of Technical Operation. Book 1: Tech OPS Business. Section 1: Maintenance Program and Philosophy. ( $4^{\text {th }}$ ed.). March 31, 2010. Ottawa.

18. NAV CANADA. (2009). Manual of Technical Operation. Book 1: Tech OPS Business. Section 2: Technical Operations Business Overview. (4 ${ }^{\text {th }}$ ed.). May 19, 2009. Ottawa.

19. NAV CANADA. (2009). Manual of Technical Operation, Book 1: Tech OPS Business. Section 3: Business Management System Processes. (4 ${ }^{\text {th }}$ ed.). May 14, 2009. Ottawa.

20. International Standard ISO/IEC. (2004). Information Technology - Process Assessment, Part 4: Guidance on use for process improvement and process capability determination. $15504-4$. ( $1^{\text {st }}$ ed.). 2004-07-01.

21. International Standard ISO/IEC. (2006). Information Technology - Process Assessment, Part 5: An exemplar Process Assessment Model. 15504-5, (1 ${ }^{\text {st }}$ ed.). 2006-03-01.

22. DFS, German Air Traffic Control. (2010). Operation Guideline for Technical Support, (V4.0 ed.). 16.11.2010. Langen.

23. DFS, German Air Traffic Control. (2009). Process Description: Provision of Maintenance S06.1. (1.4a ed.) 27.11.2009. Business Unit Center. Bremen.

24. DFS German Air Traffic Control. (2010). Service Level Agreement: CC/T-N CC/F-N, Service: Provision of technical services on location ACC Bremen. (4.0 ed.). 20.1.2010. Bremen.

25. Schraub, M. (2009). DFS German Air Traffic Control: Handbook Service Management. (1.01 ed.). 17.8.2009. Langen. 